\title{
The Verbal Paradigm in the Dialogue
}

The last two chapters were dedicated to the analysis of the verbal paradigm at the (complex-)clause level: the function of the verbal forms in embedded, dependent, and mutually dependent clauses was examined. In this and in the following two chapters, I will move on to discuss the verbal paradigms at the text level. I draw a basic distinction between three text types: the dialogue, the narrative, and the generic utterance. This distinction is based on two parameters: (a) the reference point and (b) the overall cohesive structure of the text (see above 4.3). In the present chapter, the distribution and function of the verbal forms in the dialogue will be examined. Specifically, the effect of the context of situation on the interpretation of the verbal forms will be discussed.

\subsection{Preliminaries}

Dialogue, in non-technical language, is often taken to be synonymous with conversation. In this capacity, dialogue is the form in which the most basic and ordinary language —indeed, the form which human language was primarily designed for-manifests itself.' In yet a broader sense, dialogue is conceived of as not only the most basic form of language use, but as an inextricable component thereof, for language is interactional in its very nature, a joint production' of a speaker and an addressee. ${ }^{2}$

When used in a technical fashion, however, it is important to keep the two concepts of dialogue and conversation apart: while conversation refers to a type of communicative situation, dialogue refers to a type of textual structure.

1 This idea has been expressed time and again in the literature: see Lyons, Semantics, 2, 637638 , arguing that 'there is much in the structure of languages that can only be explained on the assumption that they have developed for communication in face-to-face interaction'; also in similar wording, Levinson, Pragmatics, 54.

2 Tannen, Talking Voices, 12. In discussing the interactional nature of conversations, Tannen contends that a conversation in not simply 'a matter of two (or more) people alternately taking the role of speaker and listener', since both 'speaking and listening include elements and traces of the other'.

(C) MICHAL MARMORSTEIN, 2016 | DOI: 10.1163/9789004310483_010

This is an open access chapter distributed under the terms of the Creative Commons

Attribution-Noncommercial-Non-Derivative 3.o Unported (CC-BY-NC-ND) License 
An ordinary conversation is the most common situation in which a dialogue is realized, although other types of textual structures, such as narratives and generic utterances, may well be embedded in conversations. A literary work is another communicative situation in which dialogues are found. In this case, the dialogue may be viewed as yet another channel of story transmission, alternating with that of the narrative. Consider, for example, the following excerpt, in which the king's desire, presented in the form of direct speech, functions as a link within the sequence of events:

\section{(9.1) țumma qāla li-l-yahūdi 'inna l-malika yurīdu zìyārata-kum fa-’a'iddū nuzlan fa-'a'addü-hu}

Then he said to the Jews: 'The king wants to visit you - so prepare the food [offered to the guest]!' So they prepared it. (Riwāyāt 2, 11)

Literary or represented dialogues are considerably different from ordinary dialogues in everyday conversation. For one thing, in literary dialogues the phatic component, or references to the 'mechanical requirements of talk', are far less encountered and sometimes even completely absent. ${ }^{3}$ Secondly, in (nonperformed) literary dialogues, certain features which make up what Tannen calls 'the poetics of conversational discourse' are missing, especially those marked by prosodic means. ${ }^{4}$ Furthermore, ordinary and literary dialogues are different in their non-referential (or informative) functions. In ordinary dialogues, the social function (i.e., the establishing of the relationships among the participants) appears to exhaust much of the efforts of the interlocutors, and may be considered in some cases to constitute the ultimate goal of the conversation. Thus, one may encounter many features in ordinary conversation whose presence cannot be explained in any (better) way than the marking of involvement and rapport. ${ }^{5}$ Literary dialogues, by contrast, serve primarily an expressive function: besides transmitting information, the dialogue contributes to the

3 In her multi-dimensional model of discourse, Schiffrin, Discourse Markers, 24-25, refers to that aspect as the 'exchange structure' of discourse.

4 Tannen, Talking Voices, presents an extensive study of the features which contribute to the poetics or aesthetics of conversational discourse. These often manifest themselves through phonic or prosodic means. One could argue that punctuation marks in literary works serve a similar function. However, (original) punctuation is entirely absent from the classical works I have examined.

5 Tannen, Talking Voices, 13, argues that 'coherence and involvement are the goal—and, in frequent happy occurrences, the result—when discourse succeeds in creating meaning through familiar strategies'. 
characterization of the dramatis personae and to the overall dramatic impact of the composition. ${ }^{6}$

Dialogues, then, may vary to a great deal depending on the communicative situation is which they are realized. However, there appear to be two essential properties of dialogue which characterize this type of textual structure, regardless of the particular - spoken or written, ordinary or literary-form it assumes. The first is related to the deictic nature of the dialogue; the latter to its cohesive structure. The dialogue is egocentric: the identity of the persons involved, as well as the spatiotemporal coordinates, are all determined with respect to the speaking subject. Every utterance in a dialogue is revealing of a certain 'self', situated in a specific social and cultural context, holding a certain stance, and viewing reality from a particular vantage point. The dialogue is also interactional: it always consists of an exchange between (at least) two involved and active parties. Being egocentric and interactional, the dialogue is distinct, on the one hand, from generic utterances, which are devoid of particular reference, and on the other, from narratives (or other monologic structures), in which only one party actively contributes to discourse. These two properties largely determine (and, from the analyst's perspective, explain) the bulk of syntactic structures that are found in dialogues and the meanings they are designed to convey.

Although often taken to be the most basic form of discourse, dialogues present a tremendous structural complexity and variability. This may be explained by the fact that a dialogue is embedded in a social activity whose purpose is not simply informative, but also (and even to a greater extent) expressive and persuasive. The interactional component is therefore fundamental in analyzing the structure of dialogues. It is not without reason that speech-act theories, and pragmatics in general, were primarily oriented to dialogic utterances, since in dialogues structure and meaning are always integrated with the component of action. As Schiffrin points out, cohesion in discourse ('discourse' implying, for the most part, conversation) is achieved through a (successful) integration of these three components, i.e. structure, meaning, and action, which come into play at several dimensions: syntactic, semantic, and pragmatic. In her words: 'Local coherence in discourse is thus defined as the outcome of joint efforts from interactants to integrate knowing, meaning, saying, and doing.7

6 In literary works, the use of the same strategies that are found in ordinary conversations is never there for its own sake, but always as part of the artistic or mimetic act.

7 Schiffrin, Discourse Markers, 29. 
The structure of dialogues, then, can be approached from several angles. In the present study, the structure of dialogues in Classical Arabic prose is not explored in its entirety, but rather the discussion focuses on the verbal paradigms which operate in them. Specifically, I will examine the indicative affirmative forms occurring in main clauses, although, for the sake of coherence, a short review of the negated forms will also be presented. It should be noted that the following discussion of dialogue clauses does not fit strictly with either the standard classification of sentence-types (i.e., declarative, imperative, interrogative) or with a certain typology of speech-acts; rather, it follows from the analysis of the verbal paradigms which were found to be used in different types of clauses, thus the classification may be said to reflect both syntactic and pragmatic aspects of the examined clauses.

\subsection{Declarative Clauses}

Declarative clauses are considered to be unmarked with respect to other sentence-types (or moods). They are the most frequently occurring type of clauses and, quite often, they do not include any positive marker of their 'declarative' meaning. ${ }^{8}$ As for their use, declarative clauses are employed in the dialogue for a great number of speech-acts. The fact that they are commonly associated with a descriptive or representative function is not so much suggested by authentic linguistic evidence, as by the history of language study (or better, its philosophical sources). Proper declaratives, so to speak, which serve a purely descriptive function, are usually of generic nature (see below chapter 11). As particular clauses, declaratives in the dialogue come close to having a descriptive function when they serve to express a mental state or perception, that is, when they are used as external verbalizations of internal states or processes (see below 9.2.1). Otherwise, declaratives are often used to state a certain position or offer support to this position, that is, to express an argument. We shall see below (9.2.2) that, although no explicit marker of the declarative meaning exists, Classical Arabic does have an exponent for the argumentative function of a clause, namely, the introductory 'inna.

As mentioned above (9.1), dialogue is considered to be the most basic form of language use. For this reason, grammars usually quote examples from dialogue in order to illustrate the typical meaning of a verbal form. A clause such as presented in [9.2] could have served well the discussion of the tense-aspect opposi-

8 Cf. König and Siemund, Speech Act, $284 \mathrm{ff}$. 
tion marked by fa'ala and yaf'alu, the first indicating past perfective meaning, the latter indicating non-past (or present-future) imperfective meaning:

(9.2) wayla-kum qataltum 'abā-hu bi-l-'amsi wa-'aqtulu-hü l-yawma Woe unto you! You killed his father yesterday and am I to kill him today?! (Sira 1, 222)

There are two basic problems with such an analysis of the meanings of fa'ala and yaf'alu. Firstly, this analysis is usually generalized by the grammarians so as to account for all the cases which exist in the language (see above chapter 3 ). Secondly, it reduces the functional complexity of the verbal forms to pure, clear-cut temporal or aspectual notions. Clearly, in [9.2], as suggested by the translation, 'aqtulu-hū cannot be simply understood as an assertion of future event. Rather, this form involves the modal sense of obligation, refuted by an implied tone of reproach. But not only the interference of modal nuances in the temporal interpretation of the verbal forms challenges the neat tense-aspect opposition mentioned above. The precise meanings of tense and aspect, too, are not as self-evident as often taken to be in the frame of a dialogue. Consider, for instance, the following examples:

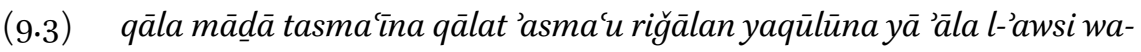
riğālan yaqūlūna yā āla l-hazraği qāla l-āna hamiya l-qitālu

He said: 'What do you hear?' She said: 'I hear men saying "O people of 'Aws [come to battle]" and men saying "O people of Hazrağ [come to battle].' 'He said: 'Now the battle is fierce.' (Riwāyāt 2, 47)

(9.4) qāla buraydatu 'arkabu l-'āna fa-'ātî-kum bi-ğam'in kațīfin min qawm-ī Burayda said: 'I will ride now and come [back] to you with a group of tough men from my people.' (Mag்āzī, 405)

In both examples the adverb l-äna 'now' is used to signal the current relevance, presence, or actuality of the events from the point of view of the speaker. Thus, in [9.3], it is hard to claim that the fa'cala form hamiya refers to a past complete event. Even if we interpret it as 'to become fierce', the impression of this process still abides at the time when the clause is uttered. The same applies to [9.4], in which the yaf'alu forms 'arkabu and 'ātī cannot be said to refer to an unapproached future, for the intention to act is already present at the time when the clause is uttered. That the speaker's 'now' coincides with both impressions (or outcomes) and intentions raises a question as to the reality of a rigidly sliced time line (at least) in the sphere of the dialogue. 
All this should not be taken to mean that tense and aspect distinctions do not exist in the dialogue, but only that they do not exist in a pure, absolute fashion. In the dialogue, temporal and aspectual meanings are always conflated with other meanings, modal or, at yet a higher level, pragmatic, which stem from the egocentricity (or subjectivity) of the dialogue and from its interactional nature.

The following discussion of declarative clauses is divided into four sections. First, plain declaratives are examined. Second, clauses introduced by the argumentative 'inna are discussed and, thereafter, asseverations taking the form of the inna la-pattern. Last, declaratives in which negative forms are used are shortly reviewed.

\subsubsection{Plain Declaratives}

Plain declarative clauses exhibit the pattern of either the verbal clause or the nominal clause, not initiated by an introductory or a modificatory operator (see above 6.2.2.2). As discussed above (4.5), there is a certain correlation between the verbal form and the clausal pattern in which it occurs, so that yaf'alu forms are more prone to occur in nominal clauses than fa'ala forms. In general, extrapositions are more common with the first person than with the second and third persons. This, too, can be explained by the egocentric nature of dialogues, in which the extensive mention of ' $\mathrm{I}$ ' is not motivated by special conditions (e.g., by contrast to another person), but serves to re-activate the most natural and accessible topic of discourse. The participle, in itself a nonfinite form, always occurs in the nominal clause pattern.

Plain declarative clauses provide a good syntactic environment to examine the interaction between the verbal lexeme (the lexical aspect) and the verbal form (the grammatical aspect). As noted above (7.2), the verbal lexeme may be characterized according to two semantic distinctions, namely, boundedness and analyzabilty into internal phases. As for the verbal forms, the distinction is drawn between forms which do not impose a certain bounding of the situation, i.e., yaf'alu, fa'ala, and fã ilun, and those which impose such bounding, i.e., sawfa/sa-yaf'alu, qad fa'ala, and maf'ülun.

The temporal value of verbs in the dialogue is determined relative to the zero-time of the dialogue. Far from its graphic representations, the zero-time of the dialogue is not simply a medial point on a logically constructed time axis. Rather, it converges with the subjective vantage-point of the speaker, with respect to which not only temporal but also aspectual and modal meanings, as well as pragmatic motivations, are determined. It will therefore be more accurate to define the reference point of the dialogue using a comprehensive term such as 'the situation of the speaker' (see above 4.2). In the following, I will 
attempt to outline the way by which the semantic and grammatical properties of the verbal form interact with the specific situation of the speaker so as to produce the set of meanings found in dialogues. I shall use relative terms such as posterior and anterior to refer to the time reference of the form, saving the absolute terms, e.g., future and past, to indicate the corresponding logical notions.

The verbal form yaf'alu, with unbounded lexemes denoting activities or states, is normally interpreted as concurrent with the zero-time of the dialogue. In [9.5]-[9.7], yaf'alu occurs with cognitive verbs, indicating perception or mental states. Although the examples exhibit all three persons, with this type of verbs, $y a f^{\prime} a l u$ is by far more attested in the first person. This may be explained by the fact that one is more inclined to make assertions about his internal state than about the mental states of others:

(9.5) 'asma'u riǧālan yaqūlūna yā 'àla l-awsi wa-riǧălan yaqūlūna yā 'àla lhazraği

I hear men saying 'O people of 'Aws [come to battle]' and men saying 'O people of Huazrağ [come to battle].' (Riwāyāt 2, 47)

(9.6) tålamu wallāhimā bi-makkata min qurašiyyin wa-lā qurašiyyatin la-hū naššun fa-șāiidan [...] 'illā wa-qad ba'ața bi-hì ma'a-nā You know, by God, there is not a man or a women in Mecca who has one našš or more [...] but he has sent it with us. (Mag்äzi, 41)

(9.7) al-hূiwānu hìwānu-hü fa-huwa yurìdu 'an yudassima-hü The table belongs to him and he wants to grease it. (Buhalä, 45)

With verbs denoting a continuous or recurring activity, such as 'abada 'to worship', yaf'alu also has a concurrent meaning:

(9.8) fa-nahnnu na'budu l-malāikata wa-l-yahūdu ta'budu 'uzayran We worship the angels while the Jews worship 'Uzayr. (Sira 1, 236)

With bounded lexemes, the verbal form yaf'alu is interpreted as having a posterior time reference relative to the zero-time of the dialogue. However, futurity expressed by yaf'alu appears to involve in most cases a modal nuance, especially in the first and second persons:

(9.9) qālā nahruğu fa-nuqātilu-hū fa-bakā wa-qāla lā tahruğā fa-wallāhi 'inna-hü la-nabiyyun 
They both said: 'We will go out and fight him.' He cried and said: 'Don't go out, for, by God, he is a prophet!' (Majāa $z \bar{\imath}, 33$ )

In [9.9] nahruğu fa-nuqātilu-hū do not express a pure prediction, but in fact, a statement about the speakers' intention to act. In such cases, intention is conflated with prediction to such an extent that one cannot regard the latter as the 'focal use' of yaf'alu..$^{9}$ Motion and action verbs such as represented by nahruğu and nuqätilu consist of both the components of intention and prediction. While intention is experienced by the speaker at the present moment of speech, prediction is less certain and always hinges upon the limited epistemological position of a particular subject (in generic clauses, by contrast, no such limits exist). Cognitive verbs, such as those illustrated above, are different from motion and action verbs in their semantic structure. In these verbs, intention and action are not so easily separable, at least in the case of feelings and sensations of which our mind is only receptive and which we normally have no control over (unless we take a deliberate, strongly intended action). However, it is not impossible (even if rare) to find yaf'alu forms which predict a certain mental state. In such cases, the reference to future time is imposed by the surrounding context. This is the case in [9.10], where the future interpretation of wa-yakrahüna 'they will hate' is entailed by the prophetic context of the clause:

\section{(9.10) wa-hādā l-baladu mawlidu-hū wa-mab'aț-hū tumma yuhriǧu-hū qaw- mu-hü min-hā wa-yakrahūna mā ğăa bi-hì}

This country is his birthplace and place of mission; then his people will expel him from there and despise what he has come with (i.e., the new faith). (Tarihh 3, 1144)

9 Bybee, Perkins, and Pagliuca, Evolution, 280, argue that 'the future is less a temporal category and more a category resembling agent-oriented and epistemic modality'. Also Lyons, Semantics, $2,815-816$, states that 'we are seldom in a position to lay claim to knowledge of the future [...]', thus the future tense 'is rarely, if ever, used solely for making statements or prediction, or posing and asking factual questions about the future. It is also used in a wider or narrower range of non-factive utterances, involving supposition, inference, wish, intention and desire'. While I agree that a pure assertion of future events is possible only for those who hold a privileged epistemological position, e.g. prophets, I do think that the component of intention or desire in a future utterance, by contrast to prediction, is very much 'factive'. For this reason, I have described [9.9] as a 'statement of intention'. Cf. also Fleischman, Future, 30, reviewing the discussion of the notion of future as a 'projection of the subjective, experiential present'. The modal value of the future is, accordingly, a projection of 'modalized notions', such as volition and obligation, which are 'rooted in the present'. 
Explicit reference to future time in the context induces a posterior reading of static verbs, whereas explicit reference to present time may induce a concurrent reading of dynamic verbs. The present time does not necessarily coincide with the exact moment of speech, but it can also be a longer span of time which forms part of the speaker's 'actual referential concern.' ${ }^{10}$ As Janssen articulately points out, 'it is the actual referential concern to the speaker that permits the event at issue to be situated, with regard to the time of the utterance, within a broad temporal region in positions that vary significantly'" Such an understanding of the meaning of the present tense, as the form marking an actual, focal, and relevant situation, obviates the otherwise puzzling questions as to the generality or semantic indefiniteness of the present tense. Thus, concurrent yaf'alu forms may equally report on momentary activities overlapping with the speech time, or on habitual activities characteristic of the present situation of the speaker:

(9.11) yā sayyid-ì l-sāata wallāhi tahruğu rūḥ-ī

My lord, now, by God, my spirit flies away. (Riwāyāt 1, 249)

(9.12) fa-qāla yā rasūla llāhi kayfa ya'ti-ka l-wahyu fa-qāla rasūlu llāhi 'ahyānan ya'tī-nì mițla șalșalati l-ğarasi

He said: 'O Messenger of God, how does the revelation come upon you?' The Messenger of God said: 'Sometimes it comes upon me like the ringing of a bell ...' (Șahịh, 4)

There are two other cases in which yaf'alu, occurring with bounded dynamic lexemes, is nonetheless interpreted as having a concurrent meaning. In these, no explicit reference to the present situation is made. In the first case, yaf'alu serves to externalize or verbalize an internal observation:

(9.13) wayla-ka tuharribu-nī ka-'annì mațlūbun

Woe to you! you force me to flee as if I were a wanted man. (Buhalä), 69)

(9.14) țumma ğa'ala ya'malu safinatan fa-yamurrūna fa-yas'alūna-hü fa-yaqūlu 'a'malu-hā safinatan fa-yasharūna min-hu wa-yaqūlūna ta'malu safinatan fì l-barrifa-kayfa tağrì

10 Janssen, Preterit as Definite, 169.

11 Ibid. 
Then he started to build an ark and they passed by and asked [what was he doing] so he said: 'I am building an ark from it.' They made fun of him and said: 'You are building an ark on land, how could it float?! (Tärih 1, 186)

In [9.13] the speaker notices that he is forced to flee, and in [9.14] the speaker (echoed later by his addressees), explains the sight about which he is asked. These examples resemble those in which perception verbs are involved (see [5] above), only in this case the clause does not communicate direct perception but an observation involving further cognitive calculation.

The second case in which dynamic yaf'alu forms may assume a concurrent reading is with speech verbs, specifically with qāla 'to say'. The saying reported by yaqülu is understood as still abiding at the time of speech. Such an interpretation of the verbal form suggests that it is not the event of saying that is being referred to, but the content of the saying:

\section{(9.15) fa-qāla lì yaqūlu la-ka 'amìru l-mu’miniña 'ağğil 'ilay-ya}

He said to me: "The Commander of the Faithful tells you: "Hurry up [and come] to me."' (Riwāyāt 1, 65)

To recapitulate the hitherto discussion of the meaning of yaf'alu in the dialogue: with unbounded, static and dynamic lexemes, yaf'alu refers to a concurrent ongoing situation; with bounded lexemes, yaf'alu is interpreted as referring to an intended posterior situation. Deviations from these general tendencies are triggered by a specific context, either one carrying an explicit reference to the future (e.g. prophecy) or one carrying an explicit reference to the present moment or situation. External verbalizations of observed situations are also concurrent with the dialogue time.

The verbal form yaf'alu can be preceded by the modifiers la-, qad, and sawfa/sa- (see above 5.2.2). The form la-yaf'alu will be discussed below in section 9.2.3. The modified qad yaf'alu is scarcely found in dialogue clauses; it is usually used in generic clauses (see below 11.3). In the dialogue, qad yaf'alu is attested with the verbs ra'a 'to see' and 'arafa 'to know', mostly in the first person. It appears that in such cases, as suggested by [9.16], qad has an assertory function: it serves to stress the validity of the assertion expressed by the plain yaf'alu:

(9.16) qum 'ilay-hi fa-qad 'arā llāha 'atā-ka bi-mā yuhzi-ka

Get up [and go] to him, for I see that God brought you something that will humiliate you. (Riwāyāt 1, 247) 
The modified form sa-yaf'alu, and to a lesser extent, sawfa yaf'alu, are more frequently attested in the dialogue. sawfa/sa-yaf'alu serve to refer to posterior occurrences, with either bounded or unbounded lexemes. With the latter types of lexemes, one can observe a neat opposition between the concurrent yaf'alu (see [6] above) and the posterior sawfa/sa-yaf'alu, as illustrated below:

(9.17) țumma ğa'ala ya'malu safinatan fa-yamurrūna fa-yas'alūna-hü fa-yaqūlu 'a'malu-hā safinatan fa-yasharūna min-hu wa-yaqūlüna ta'malu safinatan fì l-barrifa-kayfa tağrì fa-yaqūlu sawfa ta lamūna

Then he started to build an ark and they passed by and asked [what was he doing] so he said: 'I am building an ark from it.' They made fun of him and said: 'You are building an ark on land, how could it float?! So he said: 'You will know.' (Ta'rīh 1, 186)

The verbal form facala refers either to anterior occurrences, with dynamic lexemes, or to persistent situations, with stative lexemes:

(9.18) fa-qāla 'umaru yā rasūla llāhi ğìtu-ka li-ūmina bi-llāhi wa-bi-rasūli-hı̄ wa-bi-mā ğàa min-a llāhi

'Umar said: 'O Messenger of God, I came to you to express my belief in God and in His Messenger and in what he has brought from God.' (Sira 1, 227)

(9.19) fa-qāla l-rağulu 'àmantu bi-mā ğìta bi-hì

The man said: 'I believe in what you have brought.' (Șahịh, 26)

The persistent meaning of static fa'ala forms is explained by the fact that fa'ala, by contrast to qad fa'ala, does not mark the verbal situation as necessarily bounded. Thus, 'ämantu in [9.19] depicts an event whose imprints, its relevance and actuality, extend to the dialogue time. Note that the distinction between anteriority and persistence marked by fa'ala exists only in the dialogue. In the narrative, the chain structure imposes a perfective-eventive reading of facala, regardless of the type of the verbal lexeme (see below 10.2.1).

Interestingly, there is a small group of stative lexemes with which fa'ala is not used to indicate persistence but rather concurrence. Two such lexemes are șadaqa 'to tell the truth' and kadaba 'to tell lies'. When directed to the addressee, sadaqa and kadaba do not report on anterior events, but judge one's words as either true or false. To some extent, șadaqa and kadaba resemble verbs such as 'to name' or 'to appoint' in having a similar performative force (see below 
9.3). The (semi-)performativity of șadaqa and kadaba may explain their concurrent reading:

\section{(9.20) șadaqtumā wa-kaḍaba man qāla ġayra d̄ālika}

You are both right and anyone who says otherwise lies. (Sira 1, 248)

Other stative lexemes which indicate concurrence with fa'ala are šăa 'to want' and 'ahabba 'to like', when referring to a current desire of the speaker:

\section{(9.21) [...] wa-qad kabirat sinn-īwa-raqqa 'azm-ī wa-'ahbabtu liqä’a rabb-ī \\ [...] I have grown old, my bones have become tender, and I desire to meet my Lord. (Maj̇̄ zī, 213)}

In cases such as [9.21], the speaker uses fa'ala in order to mark politeness and humbleness. Such examples are particularly challenging to the common temporal-aspectual analysis of fa'ala, since it is not the past-perfective meaning of fa'ala, but its association with remoteness and indirectness, which makes this form suitable for polite requests.

In contrast to fa'ala, the verbal form qad fa'ala, with both static and dynamic lexemes, marks a bounded situation. With stative lexemes, qad facala indicates the completion of the transition from one state to another (e.g., 'not knowing' $\rightarrow$ 'knowing'):

(9.22) qad 'araftu maqālata-ka fa-rāği' 'aqla-ka wa-'Lam 'anna li-kulli' insānin manzilatan wa-qadran

I already know your position, but, reconsider the matter! Know that every man has an [assigned] status and rank! (Kalïla wa-Dimna, 66)

Resultativity, while very characteristic of qad fa'ala, is not the only meaning expressed by this form. In the sphere of the dialogue, qad fa'ala displays a complex semantic structure, consisting of a cluster of temporal, aspectual, and modal meanings. The present discussion is not aimed to determine which of these meanings is the original meaning of qad facala. ${ }^{12}$ Rather, the goal is to

12 In the Arabistic literature, one finds several attempts to explain the multiplicity of functions fulfilled by $q a d$. Testen, Asseverative la-, $85 \mathrm{ff}$., argues that the original role of $\mathrm{qad}$, from which its other meanings are derived, is the marking of perfective aspect. A different view is presented in Bahloul, Arabic Verb, chapter 5, who contends that the invariant meaning of $q a d$, underlying all of its uses, is assertorial. In my view, the existing data does not provide us with enough evidence to reach a decisive conclusion. Nevertheless, the fact 
examine the interaction of qad facala and the surrounding context in order to understand the conditions in which a certain meaning suggests itself more strongly than others.

We shall first look at a case where the temporal and aspectual meanings of qad fa'ala surface:

\section{(9.23) là tantazirū-nì bi-l-'akli fa-qad 'akaltu}

Don't wait for me with the food, for I have already eaten. (Riwāyāt 1, 40)

In [9.23] it is clear that qad 'akaltu 'I have already eaten' refers to a complete event of eating, and hence to the resultant state of satiation, which explains the speaker's request not to postpone the meal time on his behalf. In [9.24], by contrast, the emphasis lies not on the fact that the event is already completed, but on the fact that it was indeed carried out:

(9.24) wayha-ka 'a-hādā ši'ru-ka llad̄ì 'anšadta-hū l-farazdaqa qultu na'am faqāla qad wallāhi 'aṣabta wallāhi la-'in kāna hādā l-farzadaqu šăciran la-qad hasada-ka

Woe unto you, is this your poem that you sang to al-Farazdaq? I said: 'Yes.' He said: 'By God, you surely did [it] well! If this al-Farazdaq is a singer then he must envy you.' (Riwāyāt 1, 13)

The response qad 'asabta 'you did well', corroborated by the oath expression wallāhi 'by God', has an assertorial function: it stresses the fact that the event of singing exceeded the expectations of the speaker and that it is therefore remarkable.

It is interesting to notice the different uses of qad fa'ala in the dialogue vis-àvis the narrative. First of all, qad fa' ala in the dialogue may occur in main clauses whereas in the narrative it only occurs in dependent circumstantial clauses (when not embedded, see below 10.3.1). Secondly, in the dialogue, qad fa'ala is mostly used to present the background or offer an explanation to a certain position, the same as argumentative 'inna-clauses. This causal meaning of $q a d$ fa'ala is evidently related to its anterior meaning. In the narrative, on the other hand, the anterior meaning seems to predominate. Consider, for instance, the following excerpt in which the same event, viz. qad 'ahlaka, is mentioned twice, first in the dialogue and then in the narrative:

that qad fa'ala is generally incompatible with negation may be taken as evidence for the proposal that its core meaning is assertorial. 
(9.25) 'a-la 'abširū fa-qad zahara l-nağāšìyu wa-qad 'ahlaka llāhu 'aduwwahū [...] wa-rağa'a l-nağǎšiyyu wa-qad 'ahlaka llāhu 'aduwwa-hū

Rejoice, for the Negus has conquered and God has destroyed his enemy [...]; and the Negus came back after God had destroyed his enemy. (Sïra $1,221)$

In the dialogue, qad 'ahlaka clearly serves to explain the request expressed by the imperative 'abširü. In the narrative, qad 'ahlaka is part of the chronological transmission of the story. In both cases, neither the temporal nor the causal meaning can be ruled out; yet, in each of them, due to the different text type, a chronological or a logical interpretation of qad fáala suggests itself more strongly.

The active participle fä ilun, in the dialogue as elsewhere (see above 7.2), does not impose a certain bounding of the verbal situation. In contrast, the passive participle maf'ülun depicts a terminally bounded situation. With unbounded lexemes, fäilun refers to a situation concurrent with the zero-time of the dialogue. As opposed to yaf'alu, fä́ilun does not indicate an ongoing or recurring situation, but a static one:

(9.26) qad samitunna sūi raddi-hı̀ alay-kunna wa-'anā hẳifun mițla-hū minhu

You have heard his offensive reply to you and I fear of [getting] the same [reply] from him. (Riwāyāt 1, 11)

With bounded lexemes, fã ilun is interpreted as having a posterior time reference relative to the zero-time of the dialogue. In many of these cases, $f a^{-}$ilun serves to express an immediate future. ${ }^{13}$ In contrast to $y a f^{\prime} a l u$, which states the speaker's intention to take action (and, hence, predicts the occurrence of that action), fấilun states the readiness of the speaker to take action. As illustrated in [9.27], the act of going out is that settled in the speaker's mind, so as to initiate the process in effect:

\section{(9.27) fa-qāla 'utbatu lā šay'a 'anā ḩāriğun}

'Utba said: 'Nothing. I am leaving!' (Mag் $\bar{a} z \bar{\imath}, 38)$

13 Immediate future forms, according to Bybee, Perkins, and Pagliuca, Evolution, 244ff., are 'restricted to events which are imminent or about to occur in the immediate future'. As a matter of fact, immediate futures may be regarded as not futures at all, since rather than predictions, these forms amount more to 'assertions announcing the imminence of an event' (273). 
The subjective opposition between intention and readiness marked by yaf'alu and fãilun should not be simply reduced to the objective opposition between far and near future. In the dialogue, the temporal location of the events appears less important and, in fact, derives from the speaker's subjective evaluation as to the feasibility or probability of the events to take place.

The passive participle, with both bounded and unbounded lexemes, depicts a resultant state, concurrent with the zero-time of the dialogue:

(9.28) yā rasūla llāhi l-qawmu mad'ürūna faziūuna

O Messenger of God, the people are scared and frightened. (Majīzi, 54)

Table 9.1 below summarizes the discussion of the functions of the verbal forms in declarative clauses:

TABLE 9.1 The verbal forms in declarative clauses

\section{Verbal lexeme}

Verbal form

bounded

unbounded

Context/lexeme-specific

\begin{tabular}{|c|c|c|c|}
\hline yaf'alu & $\begin{array}{l}\text { concurrent } \\
\text { ongoing situation }\end{array}$ & $\begin{array}{l}\text { posterior } \\
\text { intention }\end{array}$ & $\begin{array}{l}\text { concurrent } \\
\text { explicit present }\left(l-s \bar{a}^{c} a t a\right) \\
\text { observations, sayings (yaqūlu) } \\
\text { posterior } \\
\text { explicit future (prophecy) }\end{array}$ \\
\hline$s a(w f a)-y a f^{\prime} a l u$ & \multicolumn{2}{|c|}{ posterior } & \\
\hline qadyaf'alu & & & $\begin{array}{l}\text { concurrent-assertive } \\
\text { 'arā, 'a'rifu }\end{array}$ \\
\hline fáala & persistent & anterior & $\begin{array}{l}\text { concurrent-indirect/remote } \\
s ̌ \bar{a} a, \text { 'ahabba } \\
\text { concurrent-'performative' } \\
\text { șadaqa, kaḍaba }\end{array}$ \\
\hline qad fáala & \multicolumn{2}{|c|}{ anterior-complete-causal-assertive } & \\
\hline
\end{tabular}




\section{Verbal lexeme}

Verbal form

unbounded

Context/lexeme-specific

\begin{tabular}{l|l|l|l}
\multicolumn{2}{c}{ unbounded } & \\
\hline$f a \bar{c}$ bilun & concurrent state & $\begin{array}{l}\text { posterior } \\
\text { readiness }\end{array}$ & \\
\hline maf'ūlun & \multicolumn{2}{c}{ concurrent result } & \\
\hline
\end{tabular}

\subsubsection{Argumentative 'inna-clauses}

The display of arguments constitutes a great part of any dialogue exchange. An argument, as Schiffrin defines it, is 'discourse through which speakers support disputable positions. ${ }^{14}$ It comprises, accordingly, three parts: position, dispute, and support. An argumentative clause, i.e., a clause which contributes to the construction of an argument, can be used to convey any of these parts. Quite often, clauses which express support or dispute do not follow the explicit mention of a position, but implicitly, by endorsing or rejecting a certain position, they also make plain what its content is about.

Positions, i.e., assertions about situations and events, beliefs and ideas, are often expressed by plain declaratives. However, they can also take the marked form of 'inna-clauses. The operator 'inna is used for a number of functions. ${ }^{15}$ One of its major roles is to introduce what may be described as 'expository' clauses, i.e., clauses which outline a certain position. Expository 'inna-clauses do not occur freely in the dialogue, but are found adjacent to clauses expressing commands, demands, requests or questions, whether these are directly addressed or only inferred. Expository 'inna-clauses initiate thus bipartite structures, in which the first part, the expository unit, implies the second part, the unit addressing the second party.

The verbal paradigm in expository 'inna-clauses consist of yaf'alu, fa'ala, qad fa'ala, and the participle. As far as their temporal, aspectual, and modal meanings are concerned, these forms exhibit the same distinctions as the ones observed in plain declaratives, as illustrated below:

\footnotetext{
14 Schiffrin, Discourse Markers, 18.

15 The syntactic distribution and discourse functions of 'inna were thoroughly studied in Marmorstein, 'Inna-Sentences.
} 
(9.29) 'inna-nì 'asmuru l-laylata ma'a 'amìri l-mu'minina fa-hal tuhsinu 'an tahduwa

I will spend the night chatting with the Commander of the Faithfulare you good in singing the songs which urge the camels? (Riwāaya $t$ 1, 25)

(9.3o) 'inna rağulan min 'așhābi-ka qatala rağulayni min qawm-īwa-la-humā min-ka 'amānun wa-'ahdun fa-b'aț bi-diyati-himā 'ilay-nā

A man from your companions killed two men of my people, while they had your protection and agreement, so send us their blood money! (Maḡa $\bar{a} \bar{\imath}, 364)$

(9.31) 'innī qad ğìtu bi-irsāli-ka fa-mā inda-ka

I have come with your release, what do you have at your [disposal]? (Riwāyāt 2, 190)

(9.32) yā ma šara l-'ușāti 'innì mufțirun fa-'afțirū

O people of disobedience, I am breaking my fast, so break your fast! (Majā zī, 47)

Argumentative 'inna-clauses are not only used to display a position but also to explicate a certain position or appeal to the addressee. In such cases, the bipartite structure shows an inverted order, in which the 'inna-clause follows a (direct or indirect) command, request or question. The position which explicative 'inna-clauses serve to support is often not explicitly stated, but implicit in the content of the 'inna-clause itself. The explicative 'inna thus encodes both sides of the argument (i.e., the position and the reaction to this position), thereby encapsulating its dialogic nature. ${ }^{16}$

Explicative 'inna-clauses feature the verbal forms yaf'alu, fa'ala, qad fa'ala, and the participle, and to a smaller extent, sa-yaf'alu, as illustrated in the following set of examples:

(9.33) iḥmū la-nā zuhūra-nā fa-innā nahăfu 'an nu'tā min warāì-nā Shield our backs, for we fear that we will be approached from behind us! (Maj̇̄ażi, 224)

16 According to Schiffrin, Discourse Markers, 18, arguments incorporate both monologic and dialogic properties, the latter have to do with 'the interactional organization of dispute'. The rhetoric of dispute is sometimes captured in the most compact lexical items, e.g.: Arabic's 'inna, Hebrew's harei, or car in French (for the latter, see Larcher, Le 'segmentateur', 6o). 
(9.34) 'anā 'abdu-kayā 'amīra l-mu'minīna fa-qul mā šìta siwā baššārin fa-inn̄̄ halaftu fì amri-hī bi-yaminin ġamūsin

I am your servant, O Commander of the Faithful; ask whatever you want but Baššār, for I took the gamūs-oath in his case. (Riwāyāt 1, 258)

(9.35) fa-tanahhhā nāhiyatan wa-l-samā̉u tumțiru 'alay-hiyaqūlu 'utbatu'inna hādā huwa la-nakdun wa-'inna-hum qad 'ahad̄ù suqqā'a-kum

He moved aside and the heavens rained down upon him. 'Utba said: 'This is verily a misfortune, for they have already taken your watercarriers!' (Mag் $\left.\bar{a} z \bar{\imath}, 5^{2}\right)$

(9.36) ințaliq bi-nā 'ilā ’adnā mā̉i l-qawmi fa-'innī 'ālimun bi-hā wa-bi-qulubi$h \bar{a}$

Let us go to the point nearest to the water of the people, for I know it and its wells. (Maj $\bar{a} z \bar{z}, 53)$

(9.37) uṣduq-i l-malika 'ammā sami'ta fa-innī sa-'uhaddițu-hū bi-mițti hadịți$k a$

Tell the king the truth about what you have heard, for I will give him the same account as yours. (Riwāyāt 2,193)

It is important to note that the explicative meaning may be imparted by other syntactic means, such as the connective $f a$ - The verbal form, too, specifically qad fa'ala which carries a causal meaning, is sufficient in marking the explicative relation. However, unlike the other exponents, 'inna is the only grammatical device which indicates explicitly (unambiguously) the explicative relation.

\subsubsection{Asseverative 'inna la-clauses}

Besides its argumentative function, the operator inna also has an expressive function. The fact that 'inna marks tawkid 'emphasis' was recognized by the Arab grammarians, and it is, in fact, the meaning most commonly associated with this particle. The present discussion is not concerned with the semantics of 'inna; however, some clarifications as to the distribution and use of the emphatic 'inna are deemed necessary.

It should first be stated that 'inna alone does not embody an emphatic meaning, but only when it introduces a nominal clause whose predicate is preceded by the modifier la-. Thus, the emphasis expressed by 'inna la-clauses should be attributed to the overall construction of the clause (and historically, perhaps, to the emphatic la-alone). Secondly, the exact meaning of 'emphasis', which in itself is quite vague, should be examined more closely. Emphasis can be applied 
to various parts of the predication. In the case of a verbal predication, each of its constitutive elements, i.e., the subject, the verbal lexeme, and the predicative link (the 'nexus'), can be emphasized..$^{17}$ It is the latter constitutive element, namely, the predicative relation, that the 'inna la-construction is emphasizing, thereby assigning the clause an asseverative force. The emphasizing of the predicative link, or the 'nexus focusing mechanism', is characterized by Cohen as 'a contrast of polarity applied to the nexus, or in other words, the contrast between the affirmative and the negative or even mere implication of negative, such as doubt'. ${ }^{18}$ The content to which the asseveration reacts may be explicitly stated in the surrounding context or presupposed by the speaker. Nexus focusing is viewed by Cohen as inherently modal, since it 'marks the propositional content as initially in doubt'. ${ }^{19}$ In my general classification of the verbal forms (see above chapter 5), I drew a distinction between modally unmarked (indicative) forms and modally marked forms. The employment of indicative forms in asseverative clauses is thus one case in which these acquire a specialized modal meaning (another case will be discussed in section 9.4 below). However, this meaning cannot be attributed to the verbal form alone, as it emerges from the entire construction of the clause.

The verbal paradigm in asseverative clauses consists of yaf'alu and the participle, to which the modifier $l a$ - is prefixed. Not only with unbounded, but also with bounded lexemes, yaf'alu refers to an ongoing or recurring situation, concurrent with the zero-time of the dialogue:

(9.38) hal tadrūna li-mā qāma muhammadun qà lù lā wallāhi mā nadrīwa-mā tadrì 'anta qāla balā waltawrāti 'innī la-'adrì

Do you know why Muhammad got up? They said: 'By God, we do not know and neither do you!' He said: 'But of course, by the Torah, I do know!' (Maḡa $z \bar{\imath}, 365)$

(9.40) qālat hadīğatu kallā wallāhi mā yuhzī-ka llāhu 'abadan 'inna-ka latașilu l-rahima wa-tahmilu l-kalla wa-tuksibu l-mádūma wa-taqrì ldayfa wa-tu'ìnu 'alā nawä̀ibi l-ḩaqqi

Hadīğa said: 'Never, by God, God will never disgrace you! You bestow upon the relatives, carry the burden, grant the poor with help, receive

17 For the analysis of the verbal complex into three essential constituents, viz. (1) the pronominal theme, (2) the verbal lexeme, and (3) the predicative relation between them, see Goldenberg, Verbal Structure.

18 Cohen, Modal System, 42.

19 Ibid., 67. 
hospitably the guest, and help in fulfilling the ever-recurring duties.' (Șahịh, 3)

The participle, as mentioned before, is generally used to express a static situation. However, in the frame of 'inna la-clauses, this state is interpreted as that characteristic so as to become an inherent attribute or disposition. This may be explained by the fact that nexus focusing, marked by the 'inn a la-pattern, essentially conveys a strong identification between the speaker (or more generally, the subject) and his state. Thus, also with bounded lexemes, the concurrent interpretation of la-fä ilun seems to be called for:

(9.41) wallāhi mā balag̉a-nā 'illà 'anna nabiyya-nā yușallì 'ilā l-šāmi wa-māa nurìdu'an nuhālifa-hū qāla fa-qāla 'innì la-mușallin 'ilay-hā

By God, we are only informed that our Prophet prays towards al-Šām, and we do not want to contradict him. (he said) He said: 'I am surely praying towards it (i.e. the Ka'ba).' (Sirra 1, 294)

The strong ties between asseveration, as marked by the 'inna la- pattern, and reference to present time, did not escape the Arab grammarians. Ibn Yacǐš reports on a dispute among the grammarians with regard to the possible future interpretation of la-yaf'alu. ${ }^{20}$ The grammarians allowing for a future reading of la-yaf'alu adduce the following verse from the Qurān: wa-'inna rabbu-ka la-yahkumu bayna-hum yawma l-qiyāmati (16:124) 'Verily your Lord will judge among them on the Day of Resurrection'. However, such evidence could not be found in my corpus, where all the examples of la-yaf'alu appeared as largely incompatible with a future reading. In my view, this fact is not to be explained by the disambiguating function of $l a$-, which instructs us to interpret yaf'alu as present, the same way as $s a$ - instructs us to interpret yaf'alu as future, as suggested by some grammarians. Rather, the relation between 'inna laclauses and reference to present time stems from the essential function of these clauses, namely, to emphasize the strong identification of the speaker (i.e., the topic entity) with his current state (i.e., his qualification or description). ${ }^{21}$

\subsubsection{Negative Clauses}

The present section on negative clauses in the dialogue is a short addendum to the above discussion of affirmative declarative clauses. To be sure, the topic

\footnotetext{
20 Ibn Ya'ǐ̌s, Šarh al-Mufașșal, 5, 147.

21 Unlike the stressed auxiliary 'do' in English, 'inna la- does not operate in all tenses, but is restricted to the current state of the speaker.
} 
of negation in Classical Arabic, considering both its notional and structural aspects, is worthy of a whole lot more attention. Here I will only make a few notes regarding the issues of compatibility, distribution, and frequency of some negated verbal phrases.

The Arab grammarians defined the negated verbal forms in contrast to their affirmative counterparts. Thus, Sïbawayhi presents a neat correspondence between fa'ala and its negation lam yaf'al, and between la-qad fa'ala and its negation $m \bar{a}$ fa'ala. With yaf'alu, the correspondence goes as follows: $m \bar{a}$ yaf'alu negates the present yaf'alu, whereas la yaf'alu negates both the future yaf'alu and the energetic la-yaf'alanna. ${ }^{22}$ Sibawayhi's discussion of verbal negation offers two important insights. Firstly, it reveals the polyfunctionality of the verbal forms, which-depending on their affirmative or negative realization - can be used to express different meanings. Secondly, it suggests the same connection that was observed above between emphasizing and reference to present time. These two meanings emerge from the interaction of the negative marker $m \bar{a}$ and the verbal forms fa'ala and yaf'alu, respectively. The connection between emphasis and reference to present time was lucidly explained by Wehr. ${ }^{23}$ The negative particle $m \bar{a}$, as noticed by Wehr, is usually found in dialogues, and more specifically, in contexts where an oath, asseveration, or emphasis of some other kind are involved. The primary function of $m \bar{a}$ is accordingly to mark a 'strong emotional form of speech', and to indicate high involvement on the part of the speaking subject. Since the event expressed in the clause is 'affectively stressed', it is felt by the speaker to be 'closer' to his present situation. ${ }^{24}$

The grammarians account of the verbal negation and Wehr's insightful description of $m \bar{a}$ conform with a great part of the data found in my corpus; still, some additional observations and refinements of the ones mentioned above can be offered.

The verbal form yaf'alu, when negated by $l \bar{a}$, may be interpreted as either concurrent or posterior. The time reference of lä yaf'alu is not determined by the corresponding (in fact, presupposed) affirmative form, which, we recall, can indicate both temporal values. Rather, the time reference is derived from the interaction between the verbal lexeme and the grammatical form of the verb. With unbounded lexemes, $l \bar{a}$ yaf'alu is normally interpreted as concurrent:

\footnotetext{
22 Sibawayhi, Kitāb, 1, 408-409.

23 Wehr, Arabischer Negationen.

24 Ibid., 31.
} 
(9.42) 'ayna 'abū-kiyā binta 'abì bakrin qālat qultu lā 'adrī wallāhi 'ayna 'ab-ī (Sira 1, 329)

Where is your father, O daughter of 'Abū Bakr? (she said) I said: 'I don't know, by God, where is my father.'

Contexts which include an explicit reference to future time induce a posterior reading of lā yaf'alu, also with unbounded lexemes. The negated lā yaf'alu, the same as yaf'alu, is usually not used to convey pure predictions, but to express one's intention to act or not to take action. In the first person, the intention is internal; in the second and third persons, it is projected or conjectured:

\section{(9.43) wa-innā wallāhi lā nu'minu bi-l-rahmmāni 'abadan}

And, by God, we will never believe in al-Raḥmān! (Sïra 1, 189)

As amply demonstrated by Wehr, the negative marker $m \bar{a}$ is used for expressive or 'affective' negation. Indeed, ma $y a f^{\prime} a l u$ is very common in oaths and other asseverative contexts, where reference to a future event is often intended:

\section{(9.44) fa-wallāhi mā yadhulu 'alay-ka'ahadun \\ By God, no one is to enter upon you. (Sïra 1, 249)}

The negated $m \bar{a}$ yaf'alu is also found in non-asseverative contexts. In such cases, it usually occurs with cognitive verbs indicating perception or a certain mental state or disposition. The preference of $m \bar{a}$ with cognitive verbs is to be explained by the egocentric, or better, 'centripetal force' of this negative particle, which brings the situation 'closer' to the speaker, whether this closeness stems from a strong emotional involvement or from the fact that the situation is internally experienced or sensed:

\section{(9.45) wa-mā 'uḥibbu 'an ta'lama qurayšun mā 'aqūlu l-àna} I don't want Qurayš to learn what I say now. (Mag் $\bar{a} z \bar{\imath}, 36)$

I adduce one example for the negation of yaf'alu with laysa, which in Classical Arabic prose, as opposed to Qur'ānic Arabic, is not uncommon. ${ }^{25}$ From a structural (and perhaps also historical) point of view, the compatibility of

25 Concluding his discussion of laysa in the Qurān and in Sībawayhi's Kitāb, Sakaedani, Laysa, 170-171, says that since laysa yaf'alu is not attested in the Qurān, nor mentioned by Sîbawayhi, its usage is 'supposed to be relatively recent'. However, the fact that we do 
yaf'alu with laysa - the negative counterpart of both the existential and the copulative kāna -is quite interesting: it hints at the nominal character of this type of verb (see above chapter 2), which essentially indicates nothing more than an indefinite state of affairs, which can be either asserted or denied:

(9.46) Kayfa ra'ayta bna ğāmi'in yā bunay-ya qultu la-hū 'a-wa-túfí-nī ğu'iltu fidā-ka fa-qāla lastu 'u'fi-ka fa-qul (Riwāyāt 1,3$)$

My little son, what is your opinion about Ibn Ğāmi'? I said: 'Will you exempt me [from answering], may I be made your ransom?' He said: 'I will not exempt you, so say [what do you think]!'

The negation of the verbal form fáala via $l \bar{a}$ is highly marked. The negated form la fáala, which occurs in contexts of oaths and asseverations, conveys a strong negation and refers to situations which will not take place under any type of circumstances:

(9.47) fa-qultu wallāhi lā fáaltu wa-in țalaba-nì l-halīfatu I said: 'By God, I shall not do that even if the Caliph asks me to.' (Riwāyāt $1,3)$

The negated form mā fa'ala, the same as māyaf'alu, is very common in contexts of oaths and asseverations. With both static and dynamic lexemes, it refers to situations whose imprints or relevance still abide at the time when the clause is uttered:

(9.48) 'inna-hū wallāti wal'uzzā mā nazala bi-kum 'amrun 'ázamu min d̄àlika By al-Lāt and al-'Uzzā, surely nothing greater than that has come down to you! (Mag் $\bar{a} z \bar{\imath}, 32)$

Due to the 'centripetal force' of $m \bar{a}, m \bar{a}$ fa'ala is commonly used with lexemes denoting situations which are internally perceived or sensed by the speaker:

(9.49) mā ra'aytu min-ka hayran qațtu

I have never seen any good from you. (Sahịh, 15)

find laysa yaf'alu in Classical Arabic prose proves that this is not an innovation of Modern Standard Arabic but, in fact, a fairly old form, even if not found in the corpora described by the grammarians. 
(9.50) yā habīb-ì mā 'aradtu l-wad'a min-ka bi-mā qultu-hü la-ka wa-'innamā 'aradtu tahdība-ka wa-taqwima-ka

My friend, I did not want to disparage you by what I have said, but only to improve and correct you. (Riwāyāt 1, 40)

The most common form of past negation does not involve fa'ala at all. The unmarked form of past negation is lam yaf'al: it may occur with all types of lexemes and it is not text-sensitive. Although cognitive verbs are often negated through mā fa'ala, they may also be negated through lam yaf'al:

(9.51) mā lì 'arā-ka l-yawma habìta l-nafsi wa-lam 'ara-ka mud 'ayyāmin Why is it that I see you today depressed and I haven't seen you for days?! (Kalīla wa-Dimna, 88)

Lastly, I would like to present two examples of negated participial forms. The negation of the participle can be done via $m \bar{a}$, laysa, or gayra (the latter not discussed here). Quite often, the negative particles $m \bar{a}$ or laysa are strengthened by an additional marker prefixed to the participle, namely, the preposition $b i$-. The structure of $m \bar{a}$ /laysa bi- clauses parallels the structure of 'inna la-clauses: in both cases, an operator controlling the entire clause is followed by a modifier preceding the predicate. Also, as far as their function is concerned, $m \bar{a} /$ laysa $b i$ clauses correspond to 'inna la-clauses: while 'inna la-indicates a strong association of the speaker (or agent) with a certain situation or attribute, $m \bar{a} /$ /aysa $b i$ indicates a strong dissociation of the speaker (or agent) from a certain attribute. For instance, in the famous passage quoted in [9.52], the Prophet, declaring that he does not read, dissociates himself not only from a current state of reading, but from the very ability to read:

\section{(9.52) fa-qāla iqra' fa-qultu māa 'anà bi-qārìin}

He said (i.e. the angel): 'Read!' So I Said: 'I do not read.' (Ṣaḥị̣ 5)

When not reinforced by $b i$ - and occurring with bounded lexemes, the negated participle can be interpreted as referring to an immediate future or 'current readiness':

\section{(9.53) wa-qad 'ağartu l-ğamala wa-lastu ġādiran bi-hī}

I have protected the camel and I am not about to betray him. (Kalīla wa-Dimna, 103) 
The verbal form qad facala is not found in negative declarative clauses. This may be explained by the fact that the assertorial meaning of qad is by and large incompatible with negation. However, we do find qad facala in negative interrogatives, as will be discussed and illustrated below (9.5).

\subsection{Performative Clauses}

Performative clauses are here dedicated a separate section although, from a strictly formal point of view, this type of clauses could have been subsumed under the above discussion of declaratives. Indeed, performative clauses do not employ a different mood than declaratives (like imperatives), nor do they operate on the assertive value of the clause (like interrogatives). Also from a pragmatic point of view, the preliminary Austinian distinction between 'performative' and 'constative' is blurred once one recognizes that all clauses bear some kind of illocutionary force, whether that be directly or indirectly expressed. What, then, justifies treating performatives any differently from the normal declaratives discussed above? In my view, this question cannot be settled on theoretical grounds, by espousing either one of the reductive approaches to speech-acts (the 'thesis' or 'antithesis', to use Levinson's formulation). ${ }^{26}$ Rather, it will be proper to speak of a distinct category of performatives if this indeed correlates with a special marking, lexical and/or grammatical. This condition appears to be fulfilled in Classical Arabic as will be shown below.

Performative clauses, as basically defined, are not used to say something but to do something, i.e., to bring about a change in the world, given the proper ('felicitous') conditions allowing for this change. Such a definition is rather general and may apply to a great number of clauses found in dialogues. Thus, in order to distinguish performatives from other types of clauses one must be able to specify which actions in what conditions should be considered as performatives. I define performative clauses as declarations of actions which constitute, i.e., initiate and accomplish, the action in effect. Unlike expressions of internal perception or external observations (see above 9.2.1), these declarations do not simply verbalize situations which are co-extensive with the time of speech, but refer to situations which come about through speech. Unlike imperatives or interrogatives, performatives are not designed to solicit the reaction of a sec-

26 The topic of speech acts is thoroughly discussed in Levinson, Pragmatics, chapter 5. Levinson contrasts two possible ways ('theses') to resolve the theoretical problems brought about by this topic. 
ond party (though they may affect one), but reside entirely in the domain of the speaker's desire and intention.

In Classical Arabic, one can distinguish between two major types of performative clauses: in the first, the verbal form yaf'alu is used; in the second, fa'ala and qad fa'ala are used. This distinction is not only entailed by the grammatical form of the verb, but also by its compatibility with various lexical classes. Thus, yaf'alu-performatives are lexeme-specific and occur only with declaration verbs:

(9.54) yā kašadu hal ra'ayta 'ahadan min 'uyūni muḥammadin fa-yaqūlu 'a ü $\mathbf{d}$ u bi-llāhi wa-'annā 'uyūnu muhammadin bi-l-nahbāri

O Kašad, did you see any of Muhammad's spies? He said: 'God forbid! Why are there spies of Muḥammad in Nahbār'? (Mag்āzī, 2o)

(9.55) 'udakkiru-kum-u llāha wa-dīna-kum wa-nabiyya-kum

I [hereby] remind you of God, your religion, and your Prophet. (Ma$\dot{g} \bar{a} z \bar{l}, 219)$

(9.56) 'aḥlifu bi-llāhi la-qad ğăà-kum 'usaydun bi-ġayri l-wağhi llad̄i d̆dahaba bi-hīmin inda-kum

I swear by God, 'Usayd certainly has come back to you with a different expression on his face than the one he had when he left you. (Sir 1 1, 292)

In contrast, fa'ala/qad fa'ala-performatives occur with all types of lexemes, though rarely with declaration verbs. ${ }^{27}$ This type of performatives are used in contexts where the event at issue calls for both parties' consent. In other words, in order for the event to be successfully carried out, a reciprocal approval, an agreement, is needed. I therefore refer to this type of clauses as 'transactionperformatives':

(9.57) yā rasūla llāhi bal taqsimu-hū li-l-muhāğirīna wa-yakūnūna fì dūri-nā kamā kānū wa-nādat-i l-anșāru raḍinnà wa-sallamnā yā rasūla llāhi O Messenger of God, you may rather apportion it to the Muhäğirūn and they will stay at our homes as they used to. The 'Anșār then called out: 'We are satisfied and approve [it], O Messenger of God.' (Mag்āzī, 379)

27 Grammars do quote a few examples of declaration verbs realized in the facala form, e.g.: 'anšadtu-ka llāha 'I conjure you by God' (Wright, Grammar, 2, 1). Such examples, however, are seldom found in Classical Arabic prose. 
(9.58) yā 'abā 'abdi šamsin wafat dimmatu-ka qad radadtu 'ilay-ka ğiwāra-ka O 'Abū 'Abd Šams, your obligation [to me] is completely fulfilled; I [hereby] renounce your protection. (Sira 1, 243)

(9.59) i’dan lì ahruğ 'ilā bišrin bi-l-irāqi [...] qāla qad 'adintu la-ka Allow me to go to Bišr in Iraq [...] He said: 'I [hereby] allow you.' (Riwāyāt 1, 16)

Unlike 'declaration-performaives', whose successful execution hinges solely on the speaker, without appealing to an external authority (anyone can successfully take an oath, the question of its actual worth is entirely irrelevant), 'transaction-performatives' presuppose the authority of both the speaker and his addressee to reach an agreement, i.e., to offer and accept the matter at hand.

Despite the functional differences outlined above, one cannot help but wonder how is it that yaf'alu, fa'ala, and qad fa'ala can all be used to indicate performativity? In my opinion, the appropriateness of all three forms in performative clauses is not dissociated from their temporal and aspectual meanings in regular declaratives. The form yaf'alu, as was shown above, often has a concurrent reading with speech verbs. The form facala, with stative lexemes, has a tangent point with the present situation of the speaker, and this is apparently the reason why radinna and sallamnā in [9.57] are realized in the fa'ala form rather than in the resultative qad fa'ala form. The use of qad fa'ala with potentially bounded lexemes, as in the last two examples, should be explained by the aspectual meaning of this form, indicating the completion of the verbal situation. The relation between performativity and resultativity is also apparent in the next example, featuring the passive participle:

(9.6o) mal'ūnatun-i l'arḍu llatī huliqta min-hà la'natan ḥattā tatahawwala timāru-hā šawkan

Cursed is the earth from which you were created in such a curse that its fruits will turn into thorns. (Ta'rīh 1,106$)$

There are very few examples in which performativity is expressed through a participial predicate, realizing the order of the verbal clause. The peculiar structure of [9.60] may be explained by the parallel (in fact underlying) Biblical

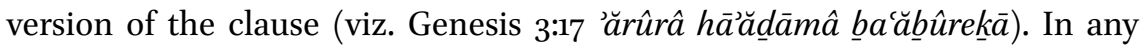
event, mal'ünatun presents us with yet another kind of performative clauses, namely, blessings and curses. When the curse is delivered by the ultimate (divine) authority, as is the case in [9.6o], it gains a performative force: it is effective as of the time of its pronunciation. This case is different from ordinary 
(human) curses, to be discussed in the following section, where the curse is a matter of a (yet unfulfilled) wish. Table 9.2 below summarizes the discussion of the distribution and function of the verbal forms in performative clauses:

TABLE 9.2 The verbal forms in performative clauses

\section{Verbal form Type of performative Temporal-aspectual value}

\begin{tabular}{lll}
\hline yaf'alu & declarative-performative & concurrence \\
fa'ala & transaction-performative & persistence \\
qadfa'ala & transaction-performative & resultativity \\
maf'ūlun & blessings and curses & resultativity
\end{tabular}

\subsection{Optative Clauses}

In Classical Arabic, the expression of wishes is not marked by a special mood, but may be realized through various syntactic means (for instance, the operator layta). What I refer to as optative clauses are but one type of clause expressing a wish. Optative clauses employ as a rule the fa'ala form, followed by the explicit mention of allāh or rabb 'God': [ fa'ala-object pron. llāh/rabb]. In the passive voice, the reference to alläh or rabb is implicit:

\section{(9.61) fa-mā hāăğatu l-'amìri 'ilay-ya ğa'ala-nī llāhu fidā-hu}

What need is there in me for the 'Amīr? May God make me his ransom! (Riwāyāt 1, 246)

\section{(9.62) ̆ǧiltu fidā-ka 'ibil-ı̄wa-'amānati}

May I be made your ransom, [what about] my camels and trusted goods? (Riwāyāt 1, 246)

As discussed earlier (9.2.3), sometimes a modally unmarked (indicative) form has a specialized modal meaning. This is the case with the optative fa'ala (as well as the conditional fa'ala which is not dealt with in the present work). Any attempt to derive the optative meaning of fa'ala from its 'basic' pastperfective meaning is bound to result in circular reasoning. ${ }^{28}$ We might get

28 Wright, Grammar, 2, $2 \mathrm{ff}$., argues that facala - when occurring in promises, oaths, condi- 
closer to understand the optative meaning of fa'ala if we examine the discursive function of these types of clauses. As shown in the examples above, the expression of wish is not intended for its own sake, but as means to show politeness and humbleness, called for in interactions with a person of a higher social stature. Earlier I discussed cases where the current desire of the speaker was expressed through fa'ala. This use of fa'ala was explained too by the indirectness or remoteness associated with fa'ala (see [9.21] above). Yet, in what may look as quite the opposite circumstances, the optative fa'ala is not only used to signal politeness in the face of nobility, but also as means to show friendliness and generosity:

(9.63) fa-qāla 'a-lā 'uhaddị̂-kum bi-mā samitu min rasūli llāhi [...] fa-qulnā balā rahima-ka llāhu

And he said: 'Will I not tell you about what I have heard from the Messenger of God [...]' And we said: 'Certainly, may God have mercy upon you!' (Ta'rīh 1, 63)

In [9.63] the speakers want to encourage their addressee to share with them the words of the Prophet, thus they use the blessing rahima-ka llähu to show rapport. That rahima-ka llähu/rabbu-ka is that conventionalized as an expression of good will is evident in the next example, where God himself is blessing Adam:

(9.64) fa-lammā nafaha fì-hi l-rūḥa fa-dahala l-rūḥu fìra'si-hì atạsa fa-qālat-i l-malāikatu qul-i l-hamdu li-llāhi fa-qāla l-ḥamdu li-llāhi fa-qāla llāhu rahima-ka rabbu-ka

And when He blew into him (i.e. Adam) the spirit and the spirit entered his head he sneezed. The angels said: 'Say "Praise be to God!' 'So he said: 'Praise be to God!' Then God said: 'May your Lord have mercy upon you!' (Ta'rīh 1, 92)

tional sentences, and wishes — has a virtually past or perfective sense, due to the certainty attributed to the occurrence 'represented as having already taken place' or 'as already fulfilled'. If indeed 'certainty' is the semantic feature underlying such uses of fa' ala, then one may rightly wonder how is it that qad fa'ala is never used in these contexts. The fact that in Post-Classical Arabic (cf. Fischer, Classical Arabic Grammar, 103), as well as in Arabic dialects, optative expressions employ as a rule the prefix conjugation rather than the suffix conjugation, is again evidence for the ad hoc validity of some aspectual-modal correlations suggested for Classical Arabic. 
I suggest, then, that the use of fa'ala in optative clauses might not be derived from its past-perfective meaning (at least not in a straightforward manner), but it is rather associated with the indirectness, remoteness, and politeness which is implied by this form..$^{29}$ The fact that optative clauses are also used for illwishing is perhaps to be explained by a generalization of the use of this pattern: once it was established for blessings, it extended to the expression of wishes of all types, including bad ones, as illustrated below: ${ }^{30}$

(9.65) fa-ḩarağa 'ilay-ya 'abū ğahlin fa-qāla marhaban wa-'ahlan yā bna 'uht¿ mā ğăa bi-ka qāla ğìtu 'uhbiru-ka 'annì qad 'āmantu bi-llāhi wa-birasūli-hī muhammadin wa-ṣaddaqtu bi-mā ğăa bi-hī qāla fa-daraba lbāba fì wağh-ì wa-qāla qabbaha-ka llāhu wa-qabbaḥa mā ğita bi-hì Then 'Abū Ğahl came out to me and said: 'Welcome! O my nephew, what has brought you?' He said: 'I came to tell you that I have become a believer in God and His Messenger Muhammad and that I regard as true what he has brought.' (he said) Then he slammed the door in my face and said: 'May God damn you and damn what you have brought!' (Sira 1, 230)

So far we have seen optative clauses in which fa'ala was employed. However, few examples feature the verbal form yaf'alu. Unlike fa'ala, the use of yaf'alu in optative clauses appears to be related in a more straightforward way to its ordinary temporal (non-past) or modal (volitive) meaning. However, by contrast to other desiderative contexts, optative yaf'alu forms are singled out by the clausal pattern in which they are realized [yaf'alu-object pron. lläh/rabb]:

(9.66) halaqa llāhu 'adama bi-yadi-hī wa-nafaha fì-hi min rūhi-hı̄ wa-’amara l-malāikata fa-sağadū la-hū fa-ğalasa fa-'ațasa fa-qāla l-ḥamdu li-llāhi fa-qūla la-hü rabbu-hü yarḥamu-ka rabbu-ka

God created Adam with His hand and blew in it some of His spirit and commanded the angels and they prostrated themselves before him. He sat down, then sneezed and said: 'Praise be to God!' His Lord said to him: 'May your Lord have mercy upon you!' (Ta'rīh 1, 156)

29 I do not deny the existence of intrinsic semantic relations between the notions of past, irrealis, indirectness and remoteness. However, I do not find any (historical or other) evidence to support the idea that temporality is more significant or original than the others. In my corpus, blessings are far more common than curses. This may have to do with the literary nature of the texts. Studies of spoken Arabic dialects show that curses are more frequent, creative, and productive than blessings, see Henkin, Cognate Curse, $169 \mathrm{ff}$. 


\section{(9.67) yaġfiru llāhu lì wa-li-l-muslimina}

May God forgive me and the Muslims! (Maj̇̄ zī, 59)

\subsection{Interrogative Clauses}

The interactional nature of dialogues finds one of its most explicit grammatical expressions in interrogative clauses. Interrogatives are 'conventionally associated with the speech act of requesting information.' ${ }^{31}$ Although this is certainly true in many cases, it is yet an oversimplification of the various functions fulfilled by interrogative clauses in discourse of any type.

In dialogues, we find numerous examples where the interrogative clearly serves a different function than 'requesting information'. For instance, an interrogative clause may serve a textural function, by setting the stage for the introduction of a new statement, offer, or request:

(9.68) qāla 'a-fa-là 'adullu-ka 'alā hayrin min deàlika qāla qultu wa-mā huwa Will I not show you a better way than that? (he said) I said: 'And what is it?' (Sira 1, 347)

Interrogatives, specifically those known as rhetorical questions, serve an expressive function. Rather than appealing to a second party to resolve some doubt, such interrogatives are used to make stronger assertions, i.e., to stress the validity or veracity of the content of the clause. Expressive interrogatives may be self-addressed or not addressed at all but merely posed, waiting for no specific answer:

(9.69) yā 'ahla makkata'a-na'kulu l-ța āma wa-nalbasu l-teiyāba wa-banū hāšimin halkā lā yubā'ūna wa-lā yubtāu min-hum

O people of Mecca, are we to eat food and wear clothes while Banū Hāšim are dying, unable to sell or buy?! (Sira 1, 248)

(9.70) 'a-yazunnu muḥammadun 'an yuṣība min-nā mā 'așāba bi-nahlata wa'așhāabu-hū

Does Muhammad think that he can get from us what he and his companions got in Nahla? (Maj̇̄ zī, 39)

$31 \quad$ König and Siemund, Speech Act, 291. 
The fact that not all interrogatives are used to express doubt or to address a second party suggests that these two properties are in fact independent from each other. Lyons accounts for this matter by distinguishing between 'asking a question of someone' and simply 'posing a question'; asking and posing are accordingly two distinct types of speech-acts, each having a different intention and each calling for a different reaction. ${ }^{32}$ Hansen, on the other hand, proposes a unified semantic-pragmatic model in which both properties of interrogatives are represented. According to this model, when asking a question, the speaker (a) 'is signaling that it is relevant for someone to wonder about the validity of the proposition expressed' and (b) 'is appealing to the hearer for a reaction to that proposition' ${ }^{33}$ The advantage of this model is that it is abstract enough to account for all types of interrogatives, whether their function is informative, expressive, or textural.

The following discussion of interrogative clauses in Classical Arabic is hardly exhaustive. I will examine only one type of interrogatives, namely yes-no questions, and focus on the functional oppositions marked by the verbal forms in these clauses.

Yes-no questions are introduced in most cases by the operators ' $a$ - or hal, though some of them are particle-less, and (as it is fair to assume) marked solely by a distinct intonation pattern. The operator ' $a$ - is prefixed to the first element of the clause. Since most interrogatives exhibit the order of the verbal clause, ' $a$ - is prefixed to the verbal form, or with negated forms, to the negation marker ( $h a l$ is also prefixed to the negation marker). In some cases, usually in expressive interrogatives, the connectives $w a$ - and $f a$ - are interposed between ' $a$ - and the (affirmative or negative) verbal form. Interrogative clauses are not marked by a special mood, but use the same indicative forms that are found in declarative clauses (see above 9.2). In the following, ' $a$-interrogatives' will be illustrated and discussed.

With unbounded lexemes, the verbal form yaf'alu in 'a-interrogatives typically indicates concurrence:

(9.71) yā 'abā ḩālidin 'a-tahāâfu 'an yubayyita-nā l-qawmu

O 'Abū Hālid, do you fear that the people will attack us at night? (Maj̄̄āi, 52)

32 Lyons, Semantics, 2, 755 .

33 Hansen, Syntax in Interaction, 467. 
With bounded lexemes, yaf'alu typically refers to posterior events. The interrogative raises doubt as to the possibility of the event to take place in some future time:

\section{(9.72) 'a-takfü-nīl-'araba}

Will you [be able to] protect me from the Arabs? (Riwāyāt 2, 184)

Put in doubt, externalized observations, with both unbounded and bounded lexemes, yield a concurrent reading of yaf'alu:

\section{(9.73) 'a-tadhabu bi-l-tạa'āmi 'ilā banì hāšimim \\ Are you taking the food to Banū Hāšim? (Sirra 1, 232)}

Interrogative clauses in which the verbal form fa'ala is used present the same opposition as in declarative clauses: with stative lexemes, fa'ala indicates persistence; with dynamic lexemes, fáala indicates anteriority. Notice that in [9.75] the interrogative takes the form of the nominal clause, which is far less attested in interrogatives than in declaratives. It may be that this pattern is used in order to lay emphasis on the nominal theme (see above 6.2.1):

(9.74) 'a-'alimta 'anna hubza l-baladìyanbutu 'alay-hi šay'un šabìhun bi-l-țini Did you know that upon the local bread there grows something like soil? (Buhalä, 89)

\section{(9.75) 'a-rabbu-ka 'ahbara-ka bi-hā}

Did your Lord tell you about that? (Sirra 1, 249)

In my corpus, I have encountered almost no examples of the verbal form qad fa'ala in interrogative clauses. The only example I did find was not introduced by ' $a$ - but initiated by the connective $w a-{ }^{34}$ The fact that qad fa'ala seldom occurs in interrogative clauses is explained by its assertorial meaning which is by and large incompatible with the expression of doubt. However, the fact that there exist a few cases in which qad fa'ala is employed in interrogatives suggests

34 In Classical Arabic, there is nothing unusual in the introduction of a new stretch of speech through the connective $w a$-. Obviously, $w a$-in this case does not simply connect one clause to the previous one. Rather, is serves the more abstract function of re-initiating the 'everongoing' dialogue that underlies speech in general (see above 9.1), somewhat like the initial 'so' in Modern English. 
that it is not the verbal situation that is put in doubt, but its strong assertion. In other words, the interrogative does not operate on the facala component but on the qad component:

\section{(9.76) wa-qad ğ $\bar{a} a$ l-hūhu ba'du}

The plums have come in already? (Buhalä', 169)

Participial forms are not encountered very often in interrogative clauses. As opposed to declarative clauses, interrogatives in which the participle is used exhibit the order of the verbal clause. In the next example, the participle occurs with a motion verb and refers to an immediate future; here, as well, it is the possibility of the event to take place that is put in doubt:

\section{(9.77) 'in tubtu wa-'aṣlaḥtu 'a-rāăǧi-ì 'anta 'ilā l-ğannati}

If I repent and improve, you might let me return to Paradise? (Ta'rīh 1, 132)

Negative interrogatives, that is, interrogatives which have in their scope a negated verbal form, are less likely to be used as neutral or open questions, to which both answers, yes or no, may equally apply. In most cases, negative interrogatives are biased toward a positive answer; rather than raising doubt, their function is to provide a certain position with more support. Thus, negative interrogatives often function as expressive interrogatives, making a certain claim and awaiting no response. ${ }^{35}$

In interrogative clauses yaf'alu is negated by $l \bar{a}, m \bar{a}$, or laysa. We observe the same temporal and aspectual meanings, as well as the same lexical preferences (e.g., the preference of $m \bar{a}$ with perception and mental verbs), that are found in declarative clauses:

(9.78) 'a-lā tarḍā yā 'abda llāhi 'anyu'țiya-ka llāhu bi-hā dāran huayran min-hā fì l-ğannati

O 'Abdallāh, are you not pleased that God will give you for it a better house in Heaven? (Sir $a 1,339)$

35 If both doubt and appealing to the hearer for response are not intended in this type of interrogatives, what, then, qualifies them as interrogatives at all? Hansen, Syntax in interaction, 470 (following Anscombre and Ducrot), suggests that such interrogatives should be analyzed as polyphonic, i.e., 'as echoing some actual, or more probably potential, utterance by someone other than the present speaker'. 
(9.79) 'a-fa-mā tarawna mā bi-kum

Don't you see what has happened to you? (Sira 1, 326)

(9.80) 'a-lastum ta'lamūna 'anna-hum 'așhāâu șāhibi-kum

Don't you know that they are the companions of your friend? (Ta'rih 6, 3276)

Negative interrogatives also exhibit the negated forms lamyaf'al and mä fáala. With stative lexemes, these refer to persistent situations, with dynamic lexemes, to anterior ones:

(9.81) 'a-lam ta'lam 'annī'ammantu l-ğamala wa-ğa'altu la-hū dimmatan Didn't you know that I reassured the camel and provided him protection? (Kalïla wa-Dimna, 103)

(9.82) subḥāna llāhi 'a-mà raḥimta-nì mimmā șana ta bì God forbid, had you no pity on me in what you did to me? (Buhalä, 166)

It was noted above that the corpus featured only one example in which qad fa'ala was used in a positive interrogative. In negative interrogatives, on the other hand, qad fa'ala was attested several times. This may be explained by the fact that negative interrogatives are biased toward a positive answer, corroborating the assertive value of the proposition. The next example presents such a case:

(9.83) 'a-wa-laysa qad mäta 'amìru l-mu'minina

Hasn't the Commander of the Faithful died yet? (Riwāyāt 2, 29)

The death of the Caliph is not truly questioned by 'a-wa-laysa qad mäta. Indeed, in this case, the question has a provocative function. It is designed to communicate the speaker's absolute repudiation of the Caliph's authority.

\subsection{Summary}

In this chapter, I have discussed the main functions of the indicative forms in dialogue texts. It was shown that although certain temporal and aspectual meanings prevail in many of the examined clause types, there is still a considerable number of semantic nuances which are context-specific, clause-specific, 
or emerge from the interaction of the verbal form with particular lexical classes. In a comprehensive account of the functions of verbs in dialogue, we cannot overlook these contexts, nor can we reduce the cluster of meanings conveyed by each form into strict temporal or aspectual notions. As we have seen, rather than expressing sheer objective temporality, verbs in dialogue are used to signal (relative values of) a variety of inter-subjective categories such as: current relevance and actuality, cognitive evaluation, emotional involvement, personal identification, directness and rapport. It is important to note that despite their correlations with specific temporal and aspectual values (e.g., 'strong emotional involvement' and 'present', or 'indirectness' and 'past'), inter-subjective meanings are not simply derived from or entailed by the more basic notions of tense and aspect. Quite the opposite in fact, they are the very purpose of the utterance in the first place. 